\title{
Impact of Deficit Irrigation, Straw Mulch and Nitrogen Fertilizer on Vegetative Growth of Maize (Zea mays L.)
}

\author{
Abarchi Idrissa $^{1^{*}}$, Maman Nouri ${ }^{2}$, Dahiratou Ibrahim Doka ${ }^{3}$, Jimoh Saka ${ }^{4}$, \\ Zhang Zhan-Y $\mathbf{u}^{5}$ and Guo Xiang-Ping ${ }^{5}$
}

${ }^{1}$ Université Dan Dicko Dankoulodo de Maradi, Faculté d'Agronomie et des

Sciences de l'Environnement, BP: 465 Maradi, Niger

${ }^{2}$ Centre Régional de la Recherche Agronomique de Maradi, Niger

${ }^{3}$ Laboratoire de mycologie, Ecole Normale Supérieure, Université Abdou Moumouni de

Niamey, BP: 10963 Niamey, Niger

${ }^{4}$ Department of Forest Resources Management, University of Ibadan, Nigeria

${ }^{5}$ Department of Agricultural Engineering, Hohai University, Nanjing 210098, China

*Corresponding author

\section{A B S T R A C T}

\section{Keywords}

Water stress, Green house, Straw mulch, Biomass, Fertilizer, Maize

Article Info

Accepted:

16 August 2018

Available Online:

10 September 2018
Water Deficit is an important limiting factor for crop growth and production in some regions of the world. It elicits several morphological responses in crop plants. Most of these responses are adaptive mechanisms to withstand water deficit or drought and to ensure both survival and reproduction. Balanced and integrated use of nitrogen fertilizer and straw mulch may enhance the accumulation of soil organic matter, improves soil physical properties and increase crop yield. Hence, impact of deficit irrigation, nitrogen fertilizer and straw mulch on the vegetative growth of maize were examined in a green house. The objective is to determine measures which will enhance resistance to drought and increase maize growth with improved soil conservation. Twelve treatments were considered by varying irrigation, rice mulch, and nitrogen fertilizer. Results obtained based on statistical analysis reveal that: (i) Mulch reduces the amount of water needed for irrigation. (ii) Mulch significantly $(\mathrm{P}<0.05)$ affect plant height, leaf number, leaf area and shoot biomass. (iii) The interactions of fertilizer mulch and fertilizer water significantly affect shoot biomass. Further field studies are needed to extrapolate the findings to a wider range of seasonal and site conditions.

\section{Introduction}

Maize (Zea mays L.) is one of the most important crops in the world, ranking third behind rice and wheat (WMO, 2012). It is now the most widely produced cereal crop with an overall production of approximately 1006.18 million tones (FAO-AMIS, 2016). Maize is currently produced on nearly 184 million hectares in 125 developing countries (FAO, 2014).

Drought is the foremost stress which decreases the production of crops worldwide (Yang et 
al., 2004). Yield losses include more than two thirds of the total damage of abiotic stresses due to drought, salinity and other factors. Maize is highly sensitive to drought, especially two weeks prior and post silking (Tollenaar and Lee, 2011). Adequate water and nutrient supply are important factors affecting optimal plant growth and successful crop production.

Moreover, application of irrigation deficit alone does not gives positive results regarding crop production or soil quality and under such critical condition, mulching may be one of the suitable alternatives to maintain optimum moisture and thermal environment in soil. The effects of rice straw mulch on crop yield and nitrogen use efficiency is inconclusive and has been shown to vary with the characteristics of the site and the climate (Erenstein, 2002). Experiences so far have highlighted positive, neutral and negative short-term yield responses to rice straw mulch. Therefore, an integrated nutrient management, in which both residue mulch and chemical Nitrogen fertilizer are simultaneously used, may be a more compatible approach in dry land.

Several studies have reported that Farm yard manure plus inorganic $\mathrm{N}$ applications in irrigated systems resulted in reduced bulk density, higher soil organic matter and hydraulic conductivity and improved soil structure and microbial communities (Bhattacharyya et al., 2007). Kaur et al., (2008) stated that a judicious combination of organic amendments and inorganic fertilizers is widely recognized strategy of integrated nutrient management to sustain agronomic productivity and improve soil fertility.

There is very scanty information on the vegetative growth of maize when exposed to water stress at seedling stage under the condition of mulch, especially when chemical fertilizer was applied after water recovery from stress. Thus, the objectives of the study are:

To evaluate the impact of water stress on the growth of maize.

To appraise specifically the effect of mulch and fertilizer on the growth of maize.

To examine the interactive effects of irrigation water supply, crop residues mulch and fertilization on vegetative growth of maize.

\section{Materials and Methods}

\section{Experimental site}

A greenhouse experiment was carried out in 2005 and 2006 at the experimental farm of Agricultural Engineering Department, Hohai University, Nanjing, China $\left(31^{\circ} 95^{\prime} \mathrm{N}\right.$ latitude and $118^{\circ} 83^{\prime} \mathrm{E}$ longitude). The climate is sub humid with an average annual rainfall of 1106 millimeter ( $\mathrm{mm})$.

The soil of the experimental site is clay loam with $33.81 \%$ clay, $65 \%$ silt, $0.97 \%$ sand and a $\mathrm{pH}$ (1:2.5 soil: water) of 7.96 . The organic matter content is $12.26 \mathrm{mg} \mathrm{kg}^{-1}$. The available nitrogen and available phosphorus are 47.4 and $10.13 \mathrm{mg} \mathrm{kg}^{-1}$ respectively. Nanjing Agricultural University Maize Variety 108 (Nongda 108) was used as a test crop. Nongda 108 was planted on June 19 and harvested on October 17 in 2005 and 2006.

\section{Experimental details}

The experimental design is a Randomized Complete Block Design with three replications. Twelve treatments were considered (Table 1). Each plot is $2.25 \mathrm{~m} \times 1.5$ $\mathrm{m}$. The seeds were sown at $5 \mathrm{~cm}$ depth and 40 x30 cm row spacing in plots. Five (5) seeds were planted in each hole and thinned to 1 after two weeks of emergence. So, each plot 
has 30 plants. Prior to sowing; urea was applied in rows $10 \mathrm{~cm}$ deep at the rate of 375 $\mathrm{kg} \mathrm{ha}^{-1}$ for all plots. The first weeding was carried out at two weeks after planting. Rice residues were applied as mulch at the rate of 6 $\mathrm{t} \mathrm{ha}^{-1}, 15$ days after maize emergence to some plots. Mulch residues have been cut into pieces of nearly $5 \mathrm{~cm}$ prior to application.

Plant parameters measurements started 3 weeks after plant emergence, which is when $40 \%$ of plants have 5 leaves. Plant diameter that is maize stem was measured with a Vernier Caliper at $5 \mathrm{~cm}$ above the ground, while plant height was measured with a measuring tape, and leaf area, with a ruler and results calculated based on the formula below:

$\mathrm{L} A=0.75 * \mathrm{Lm} * \mathrm{Wm}$

Where,

LA is the leaf area of maize; Lm is length of maize leaf and $\mathrm{Wm}$ the width. The total area was calculated by summing up individual leaf area, and in counting the number of leaves, dry leaves were not been considered. Plant height, number of leaves, leaf area and plant diameter were measured every two weeks from July $13^{\text {th }}$ to September $24^{\text {th }}$ in 2005 and 2006. Plants were exposed to stress at seedling stage at 31 Days after planting (DAP). At the end of stress time, that is at 45 DAP, fertilizer urea $\left(\mathrm{CO}\left(\mathrm{NH}_{2}\right)_{2}\right)$ at the rate of $240 \mathrm{~kg} \mathrm{ha}^{-1}$ was applied to some plots. Harvesting was done on October $17^{\text {th }}$ each year. For analysis, shoot and root biomass were taken, oven dried for 72 hours at $65^{\circ} \mathrm{C}$ and thereafter weighed.

Soil water content at 0-60 $\mathrm{cm}$ depth was measured with neutron probe meter at intervals of 7-10 days. The water absorbed from the soil for a given interval was taken as the decrease in soil water in $0-60 \mathrm{~cm}$ depth interval. Evapotranspiration for the same interval was considered to be the total amount of water absorbed from the soil plus irrigated water.

\section{Statistical analyses}

All statistical analyses were performed using General Linear Models (GLM) procedures in SPSS, Version 20 package. Three way ANOVA analyses were carried out over all twelve treatments to test explicitly the effects of deficit irrigation, mulch and fertilizer on growth parameters of maize. Water application, mulch and fertilizer were treated as fixed factors in all the analyses while plant diameter, height, number of leaves, leaf area, plant biomass as dependent variables. Correlation analyses were carried out between number of leaves and plant diameter, plant height and leaf area.

\section{Results and Discussion}

\section{Irrigation water used}

Table 2 shows the irrigation water used in millimeters for different treatments during the growing of maize. Mulch reduces the amount of water need for irrigation by $11.63 \%, 6.36 \%$ and $6.10 \%$ under full irrigation, mild and severe stress treatments in 2005. In 2006, the decrease was $13.71 \%, 4.95 \%$ and $7.47 \%$ for full irrigation, mild and severe stress respectively. Chakraborty et al., (2008) indicated that mulching reduces unproductive evaporation from the soil surface, so more water is available for transpiration, which is of benefit in water limited conditions and plant water status is maintained. Similar findings were reported by Rahman et al., (2005).

\section{Stem diameter and plant height}

Figure 1 showed the stem diameter of maize in response to varying treatments in 2005 and 2006 respectively. The results indicated that the highest stem diameter $(13.91 \mathrm{~cm})$ in 2005 
and $(13.80 \mathrm{~cm})$ in 2006 were obtained under no mulch full irrigation plus fertilizer (-M$\mathrm{S}+\mathrm{F}$ ) treatment and plus mulch full irrigation plus fertilizer $(+\mathrm{M}-\mathrm{S}+\mathrm{F})$ treatment. Various researchers reported that continuous availability of water improve the stem diameter in maize (Dogan and Kimak, 2010) and established the need of higher irrigation for better plant girth (Stone et al., 2006). Both, fertilizer, mulch, water and their interaction did not have any significant effect on stem diameter. Only the interaction of fertilizer and water application affect stem diameter at 13 Weeks after planting (WAP) (Figure 1). However, in 2006, mulch significantly ( $p<$ 0.05 ) affect stem diameter during maize growth (Figure 1). A decrease observed at 13 WAP is due to the period of maturity.

The effect of the treatment applications (water, mulching, fertilizer and the combination of treatments) on maize height are shown in Figure 2. In 2005, the maximum plant height $(1.98 \mathrm{~m})$ was obtained at 9 WAP for no mulch full irrigation plus fertilizer (-M$\mathrm{S}+\mathrm{F}$ ) (Figure 2a). Irrigation plays a vital role in vegetative growth of plant and causing improvement in plant height. Findings of present study are similar to the findings of Yazar et al., (2012) who observed highest maize plant height in full irrigation. Similarly, English, 2010 suggested that, maize crop are highly sensitive to drought stress conditions. Tahir et al., (2006) reported increase in plant height and spike length with increasing amount of irrigation. Higher application rate of fertilizer resulted in taller plant. Cheema et al., 2001 also described the increase in plant height and spike length with the application of phosphorus fertilizers. In 2006, the no mulch plus mild stress no fertilizer (-M+S1-F) treatment had the highest $(2.01 \mathrm{~m})$ plant height (Figure 2d). Mulch significantly $(\mathrm{p}<0.05)$ affect plant height at 11 and 13 WAP in 2005 and 2006 respectively. These results concurred with those of Makus et al., (1994) who observed that plant height was significantly affected by different mulching materials.

\section{Number of leaves, leaf area and Shoot biomass}

The numbers of leaves in response to varying treatments are presented in Figure 3. Both mulch and fertilizer have no significant effect on number of leaves in 2005. While, water significantly affects number of leaves (Figure $3)$. The highest number of leaves (13.80) in 2005 and (12.83) in 2006 were recorded at 9 WAP for no mulch mild stress no fertilizer ($\mathrm{M}+\mathrm{S} 1-\mathrm{F})$ and plus mulch mild stress no fertilizer $(+\mathrm{M}+\mathrm{S} 1-\mathrm{F})$ (Figures $3 \mathrm{c}$ and $3 \mathrm{~d})$. During the second year of cropping period, mulch significantly affect number of leaves, except at 3 WAP. The number of leaves gradually increased with increasing irrigation frequency. The results are in agreement with the findings of Bozkurt et al., (2011) in Mediterranean climatic conditions. Yildirim and Kodal, (2008) reported that seasonal rainfall ranging from 30 to $120 \mathrm{~cm}$ produced maximum effective leaves in maize in Ankara, Turkey. Our results corroborate with those of Lamn et al., (2005) who stated that deficit irrigation reduced the number of leaves. Figure 4 represent leaf area of maize in 2005 and 2006 respectively. Mulch, fertilizer and their interaction have no significant effect on leaf area in 2005. However, in 2006, leaf area is significantly $(\mathrm{p}<0.05)$ affected by mulch at 9, 11 and 13 WAP (Figure 4). Maximum leaf area $\left(4460.09 \mathrm{~cm}^{2}\right)$ in 2005 was observed at 9 WAP in those plots in which there is fertilizer, severe stress and no mulch $(-\mathrm{M}+\mathrm{S} 2+\mathrm{F})$ followed by $4439.96 \mathrm{~cm}^{2}$ in plots which was treated with fertilizer full irrigation without mulch (-M-S+F). In 2006, maximum leaf area $\left(4406.11 \mathrm{~cm}^{2}\right)$ was recorded at 9 WAP in plots treated with mulch mild stress without fertilizer followed by $4239.70 \mathrm{~cm}^{2}$ in the plots which was treated with fertilizer full irrigation and mulch. 
Table.1 Treatments combinations for maize

\begin{tabular}{|c|c|c|c|}
\hline $\begin{array}{l}\text { Treatmen } \\
\text { ts }\end{array}$ & Soil moisture ${ }^{3)}$ & Combination $^{2)}$ & Descriptions ${ }^{1)}$ \\
\hline 1 & $70 \%-100 \%$ & -M-F-S & No mulch No fertilizer No stress \\
\hline 2 & & $-\mathrm{M}+\mathrm{F}-\mathrm{S}$ & No mulch Plus fertilizer No stress \\
\hline 3 & & $+\mathrm{M}-\mathrm{F}-\mathrm{S}$ & Plus mulch No fertilizer No stress \\
\hline 4 & & $+\mathrm{M}+\mathrm{F}-\mathrm{S}$ & Plus mulch Plus fertilizer No stress \\
\hline 5 & $55 \%-65 \%$ & $-\mathrm{M}-\mathrm{F}+\mathrm{S} 1$ & No mulch No fertilizer Plus mild stress ${ }^{*}$ \\
\hline 6 & & $-\mathrm{M}+\mathrm{F}+\mathrm{S} 1$ & No mulch Plus fertilizer Plus mild stress ${ }^{*}$ \\
\hline 7 & & $+\mathrm{M}-\mathrm{F}+\mathrm{S} 1$ & Plus mulch No fertilizer Plus mild stress * \\
\hline 8 & & $+\mathrm{M}+\mathrm{F}+\mathrm{S} 1$ & Plus mulch Plus fertilizer Plus mild stress \\
\hline 9 & $45 \%-55 \%$ & $-\mathrm{M}-\mathrm{F}+\mathrm{S} 2$ & No mulch No fertilizer Plus severe stress ${ }^{*}$ \\
\hline 10 & & $-\mathrm{M}+\mathrm{F}+\mathrm{S} 2$ & No mulch Plus fertilizer Plus severe stress ${ }^{*}$ \\
\hline 11 & & $+\mathrm{M}-\mathrm{F}+\mathrm{S} 2$ & Plus mulch No fertilizer Plus severe stress ${ }^{*}$ \\
\hline 12 & & $+\mathrm{M}+\mathrm{F}+\mathrm{S} 2$ & Plus mulch Plus fertilizer Plus severe stress \\
\hline \multicolumn{4}{|c|}{$\begin{array}{l}\text { 1) * At seedling stage } ;{ }^{2)} \mathrm{M} \text { : Mulch; F: Fertilizer; S: Full irrigation; S1: Mild stress; S2: Severe stress. } \\
\text { 3) } 70 \%-100 \% \text { represent the maximum and minimum moisture content for full irrigation treatments; } 55 \%-65 \% \\
\text { represent the maximum and minimum moisture content for mild stress treatments; } 45 \%-55 \% \text { represent the } \\
\text { maximum and minimum moisture content for severe stress treatments. Those values represent the percentage of } \\
\text { field capacity }\end{array}$} \\
\hline
\end{tabular}

Table.2 Irrigation water used in millimeters for different treatments during the growing of maize

\begin{tabular}{|c|c|c|c|c|c|c|c|c|c|c|c|c|c|}
\hline \multirow[t]{2}{*}{ Year } & \multirow[t]{2}{*}{$\mathbf{D A S}^{1)}$} & \multicolumn{12}{|c|}{ Amounts of water used for the different treatments ${ }^{2)}$} \\
\hline & & T1 & $\mathbf{T} 2$ & T3 & T4 & T5 & T6 & T7 & T8 & T9 & T10 & T11 & T12 \\
\hline \multirow[t]{8}{*}{2005} & 1 & 56 & 56 & 56 & 56 & 56 & 56 & 56 & 56 & 56 & 56 & 56 & 56 \\
\hline & 4 & 24 & 24 & 24 & 24 & 24 & 24 & 24 & 24 & 24 & 24 & 24 & 24 \\
\hline & 21 & 18 & 18 & 18 & 18 & 18 & 18 & 18 & 18 & 18 & 18 & 18 & 18 \\
\hline & 32 & 27 & 26 & 10 & 10 & 5 & & & & & & & \\
\hline & 48 & 32 & 19 & 24 & 23 & 30 & 31 & & 25 & & & & \\
\hline & 64 & 27 & 33 & 34 & 34 & 23 & 24 & 34 & 19 & 32 & 38 & 28 & 25 \\
\hline & 82 & 38 & 38 & 30 & 25 & 19 & 29 & 32 & 20 & 27 & 23 & 22 & 24 \\
\hline & Total & 222 & 214 & 196 & 190 & 175 & 182 & 164 & 162 & 157 & 159 & 148 & 147 \\
\hline \multirow[t]{9}{*}{2006} & 1 & 18 & 18 & 18 & 18 & 18 & 18 & 18 & 18 & 18 & 18 & 18 & 18 \\
\hline & 10 & 24 & 24 & 24 & 24 & 24 & 24 & 24 & 24 & 24 & 24 & 24 & 24 \\
\hline & 22 & 07 & 05 & 05 & 05 & 04 & 04 & 05 & 05 & 02 & 06 & 05 & 03 \\
\hline & 30 & 23 & 22 & 13 & 19 & 05 & 07 & & & & & & \\
\hline & 36 & 18 & 22 & 17 & 20 & 21 & 20 & 14 & & & & & \\
\hline & 48 & 36 & 29 & 29 & 29 & 26 & 22 & 26 & 31 & 39 & 39 & 37 & 36 \\
\hline & 60 & 34 & 25 & 30 & 24 & 21 & 22 & 20 & 26 & 18 & 15 & 23 & 23 \\
\hline & 75 & 34 & 28 & 29 & 30 & 29 & 28 & 31 & 30 & 22 & 23 & 10 & 12 \\
\hline & $\begin{array}{c}95 \\
\text { Total }\end{array}$ & $\begin{array}{c}30 \\
224\end{array}$ & $\begin{array}{c}33 \\
206\end{array}$ & $\begin{array}{c}31 \\
196\end{array}$ & $\begin{array}{c}19 \\
188\end{array}$ & $\begin{array}{c}23 \\
171\end{array}$ & $\begin{array}{c}24 \\
169\end{array}$ & $\begin{array}{c}25 \\
163\end{array}$ & $\begin{array}{c}27 \\
161 \\
\end{array}$ & $\begin{array}{c}34 \\
157\end{array}$ & $\begin{array}{c}30 \\
155\end{array}$ & $\begin{array}{c}29 \\
146\end{array}$ & $\begin{array}{c}23 \\
139\end{array}$ \\
\hline
\end{tabular}

${ }^{1)}$ DAS: Days after sowing, ${ }^{2)} \mathrm{T}$ : treatment 
Table.3 Shoot biomass of maize ( $\left(\mathrm{ha}^{-1}\right)$ in 2005 and 2006

\begin{tabular}{|l|l|l|}
\hline & \multicolumn{2}{|c|}{ Years } \\
\hline & $\mathbf{2 0 0 5}$ & $\mathbf{2 0 0 6}$ \\
\hline -M-F-S & 3.71 & 5.18 \\
\hline -M+F-S & 4.16 & 6.22 \\
\hline$+\mathrm{M}-\mathrm{F}-\mathrm{S}$ & 4.26 & 4.65 \\
\hline$+\mathrm{M}+\mathrm{F}-\mathrm{S}$ & 4.02 & 6.30 \\
\hline -M-F+S1 & 6.56 & 6.70 \\
\hline$-\mathrm{M}+\mathrm{F}+\mathrm{S} 1$ & 3.13 & 4.82 \\
\hline$+\mathrm{M}-\mathrm{F}+\mathrm{S} 1$ & 4.32 & 5.35 \\
\hline$+\mathrm{M}+\mathrm{F}+\mathrm{S} 1$ & 3.63 & 6.81 \\
\hline$-\mathrm{M}-\mathrm{F}+\mathrm{S} 2$ & 5.05 & 5.97 \\
\hline$-\mathrm{M}+\mathrm{F}+\mathrm{S} 2$ & 5.27 & 4.81 \\
\hline$+\mathrm{M}-\mathrm{F}+\mathrm{S} 2$ & 4.50 & 6.34 \\
\hline$+\mathrm{M}+\mathrm{F}+\mathrm{S} 2$ & 3.46 & 6.06 \\
\hline
\end{tabular}

Table.4 Correlations of different growth parameters in 2005

\begin{tabular}{|c|c|c|c|c|c|}
\hline \multirow[t]{2}{*}{$\mathbf{W A P}^{1)}$} & \multirow[t]{2}{*}{ Parameters } & \multicolumn{4}{|c|}{ Parameters ${ }^{2)}$} \\
\hline & & SD & PH & NL & LA \\
\hline \multirow[t]{4}{*}{3} & SD & 1.000 & $0.915 * *$ & $0.889 * *$ & $0.920 * *$ \\
\hline & PH & & 1.000 & $0.827 * *$ & $0.895 * *$ \\
\hline & NL & & & 1.000 & $0.893 * *$ \\
\hline & LA & & & & 1.000 \\
\hline \multirow{5}{*}{5} & & & & & \\
\hline & SD & 1.000 & $0.849 * *$ & $0.865 * *$ & $0.871 * *$ \\
\hline & PH & & 1.000 & $0.849 * *$ & $0.875 * *$ \\
\hline & NL & & & 1.000 & $0.875^{* * *}$ \\
\hline & LA & & & & 1.000 \\
\hline \multirow[t]{4}{*}{7} & SD & 1.000 & $0.861 * *$ & $0.808 * *$ & 0.832 \\
\hline & $\mathrm{PH}$ & & 1.000 & $0.865^{* *}$ & 0.851 \\
\hline & NL & & & 1.000 & 0.807 \\
\hline & LA & & & & 1.000 \\
\hline \multirow{4}{*}{9} & SD & 1.000 & $0.749 * *$ & $0.263 *$ & $0.844 * *$ \\
\hline & $\mathrm{PH}$ & & 1.000 & $0.260 *$ & $0.798 * *$ \\
\hline & NL & & & 1.000 & $0.345 * *$ \\
\hline & LA & & & & 1.000 \\
\hline \multirow[t]{4}{*}{11} & SD & 1.000 & $0.649 * *$ & $0.311 * *$ & $0.743 * *$ \\
\hline & $\mathrm{PH}$ & & 1.000 & $0.234 * *$ & $0.893^{* * *}$ \\
\hline & NL & & & 1.000 & $0.328 * *$ \\
\hline & LA & & & & 1.000 \\
\hline \multirow[t]{4}{*}{13} & SD & 1.000 & $0.636 * *$ & $0.348 * *$ & $0.764 * *$ \\
\hline & PH & & 1.000 & 0.207 & $0.889 * *$ \\
\hline & NL & & & 1.000 & $0.349 * *$ \\
\hline & LA & & & & 1.000 \\
\hline
\end{tabular}

1) WAP: weeks after planting, ${ }^{2)}$ SD: stem diameter, PH: plant height, NL: number of leaves, LA, leaf area, ** Correlation is significant at the 0.01 level, * Correlation is significant at the 0.05 level 
Table.5 Correlations of different growth parameters in 2006

\begin{tabular}{|c|c|c|c|c|c|}
\hline \multirow[t]{2}{*}{ WAP $^{1)}$} & \multirow[t]{2}{*}{ Parameters } & \multicolumn{4}{|c|}{ Parameters ${ }^{2)}$} \\
\hline & & SD & PH & NL & LA \\
\hline \multirow[t]{4}{*}{3} & SD & 1.000 & $0.940 * *$ & $0.772 * *$ & $0.905^{* * *}$ \\
\hline & $\mathrm{PH}$ & & 1.000 & $0.722 * *$ & $0.875^{* *}$ \\
\hline & NL & & & 1.000 & 0.777 *** \\
\hline & LA & & & & 1.000 \\
\hline \multirow[t]{4}{*}{5} & SD & 1.000 & $0.800 * *$ & $0.763^{* *}$ & $0.849 * *$ \\
\hline & $\mathrm{PH}$ & & 1.000 & $0.805^{* *}$ & $0.923 * *$ \\
\hline & NL & & & 1.000 & $0.874 \%$ \\
\hline & LA & & & & 1.000 \\
\hline \multirow[t]{4}{*}{7} & SD & 1.000 & $0.800^{* *}$ & $0.763^{* *}$ & $0.877^{* * *}$ \\
\hline & $\mathrm{PH}$ & & 1.000 & $0.805^{* *}$ & $0.936^{* * *}$ \\
\hline & NL & & & 1.000 & $0.868 \%$ \\
\hline & LA & & & & 1.000 \\
\hline \multirow[t]{4}{*}{9} & SD & 1.000 & $0.787 * *$ & $0.610^{* * *}$ & $0.865^{* * *}$ \\
\hline & $\mathrm{PH}$ & & 1.000 & $0.638 * *$ & 0.912 *** \\
\hline & NL & & & 1.000 & $0.684^{* * *}$ \\
\hline & LA & & & & 1.000 \\
\hline \multirow[t]{4}{*}{11} & SD & 1.000 & $0.821^{* *}$ & $0.623^{* *}$ & $0.890 * * *$ \\
\hline & PH & & 1.000 & $0.605^{* *}$ & $0.895^{* * *}$ \\
\hline & NL & & & 1.000 & $0.699 * *$ \\
\hline & LA & & & & 1.000 \\
\hline \multirow[t]{4}{*}{13} & SD & 1.000 & $0.818^{* *}$ & $0.311^{* *}$ & $0.885^{* * * *}$ \\
\hline & $\mathrm{PH}$ & & 1.000 & $0.286^{* * *}$ & $0.895^{* * * *}$ \\
\hline & NL & & & 1.000 & $0.699 * \%$ \\
\hline & LA & & & & 1.000 \\
\hline
\end{tabular}

${ }^{1)}$ WAP: weeks after planting, ${ }^{2)}$ SD: stem diameter, PH: plant height, NL: number of leaves, LA, leaf area, ** Correlation is significant at the 0.01 level, * Correlation is significant at the 0.05 level 

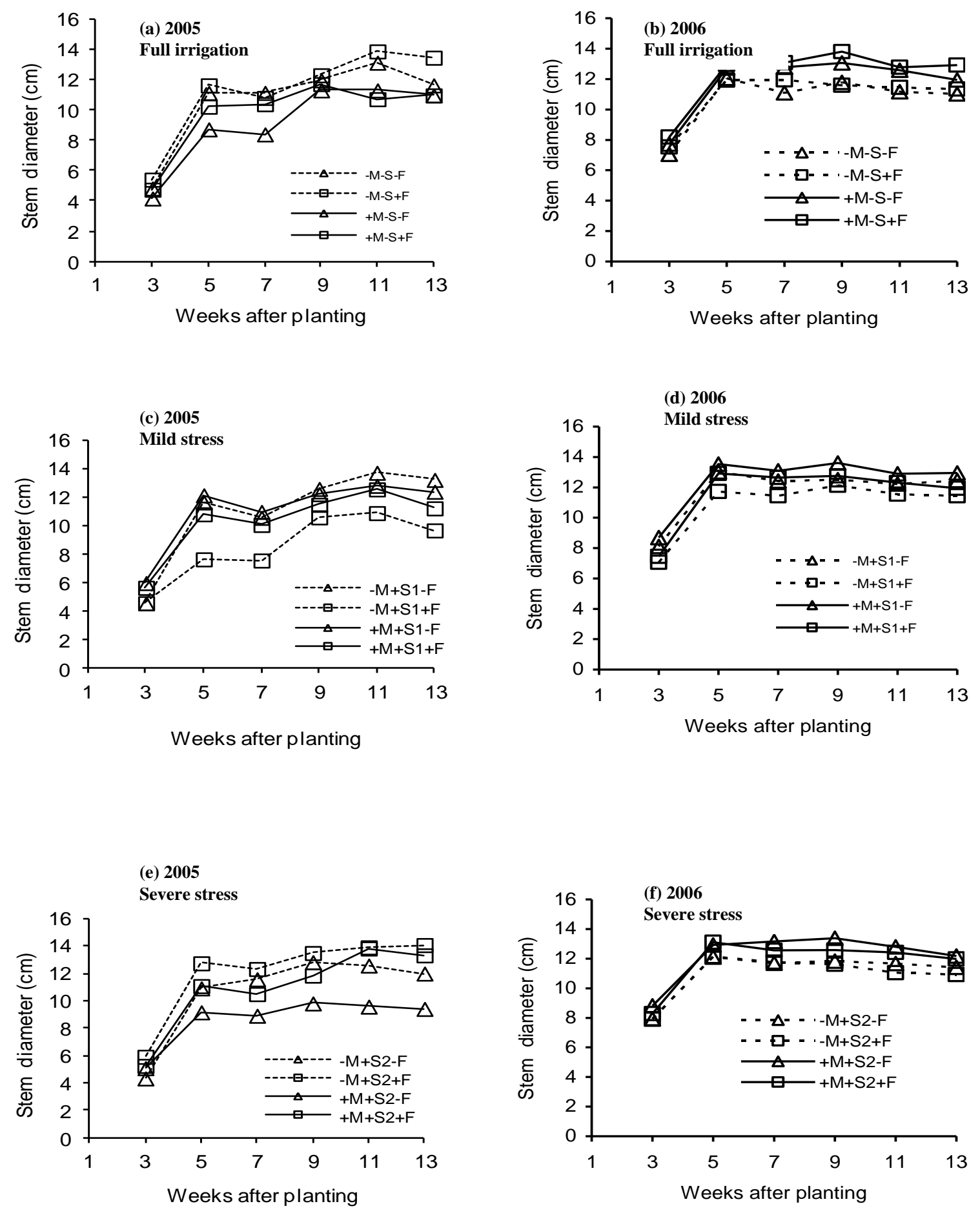

Fig.1 Stem diameter of maize in response to varying treatment in 2005 and 2006 

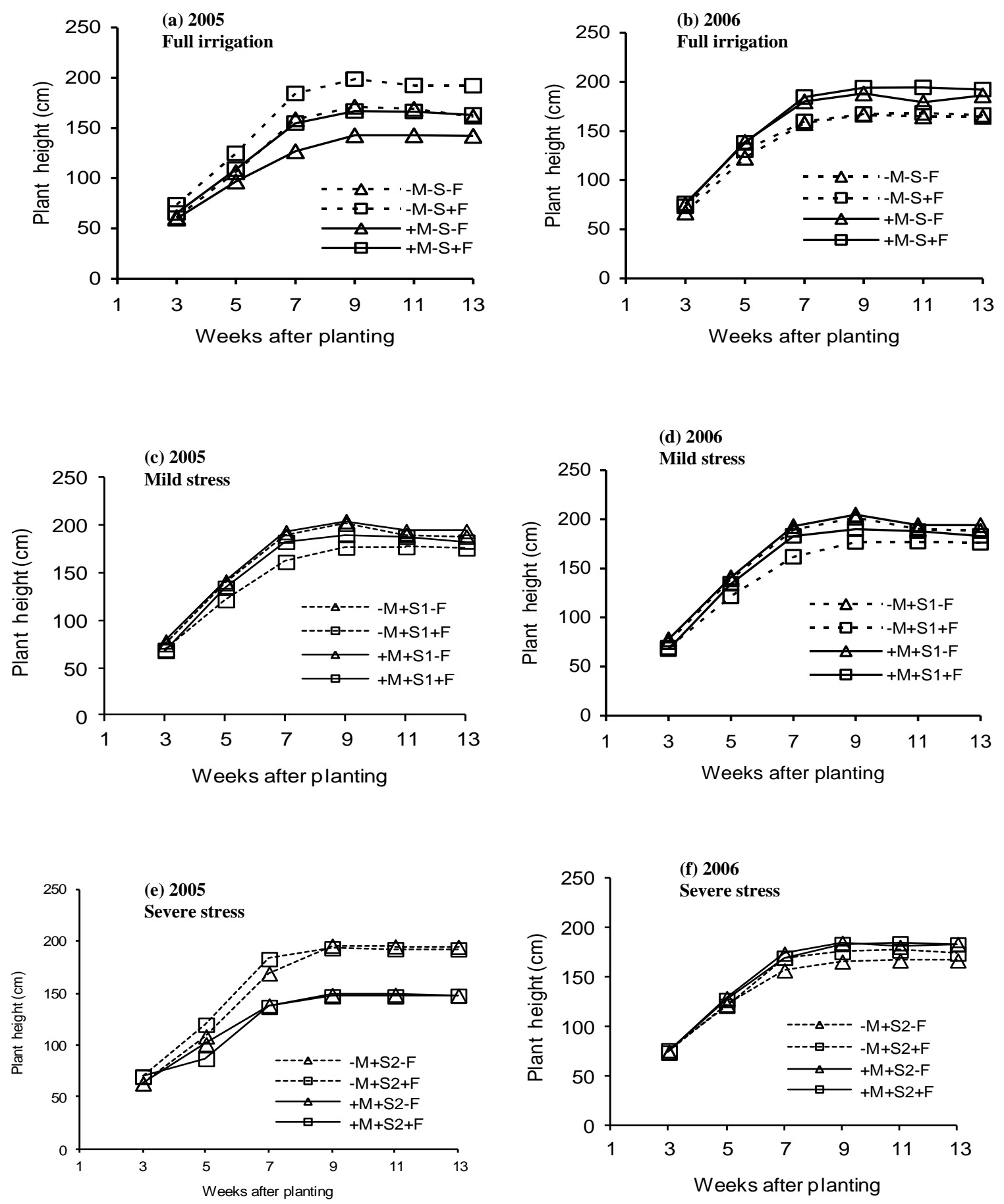

Fig.2 Plant height of maize in response to varying treatment in 2005 and 2006 

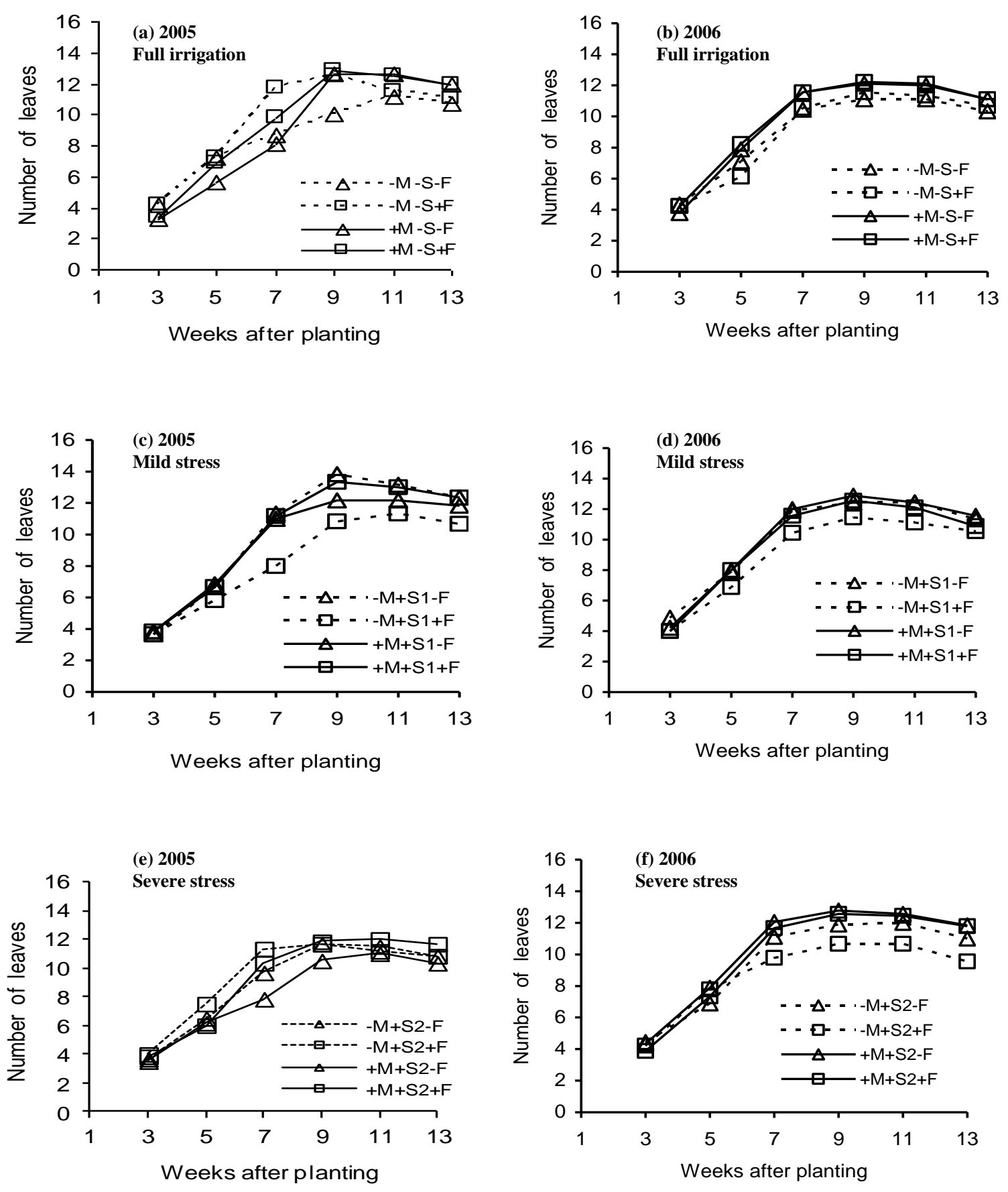

Fig.3 Number of leaves of maize in response to varying treatment in 2005 and 2006 

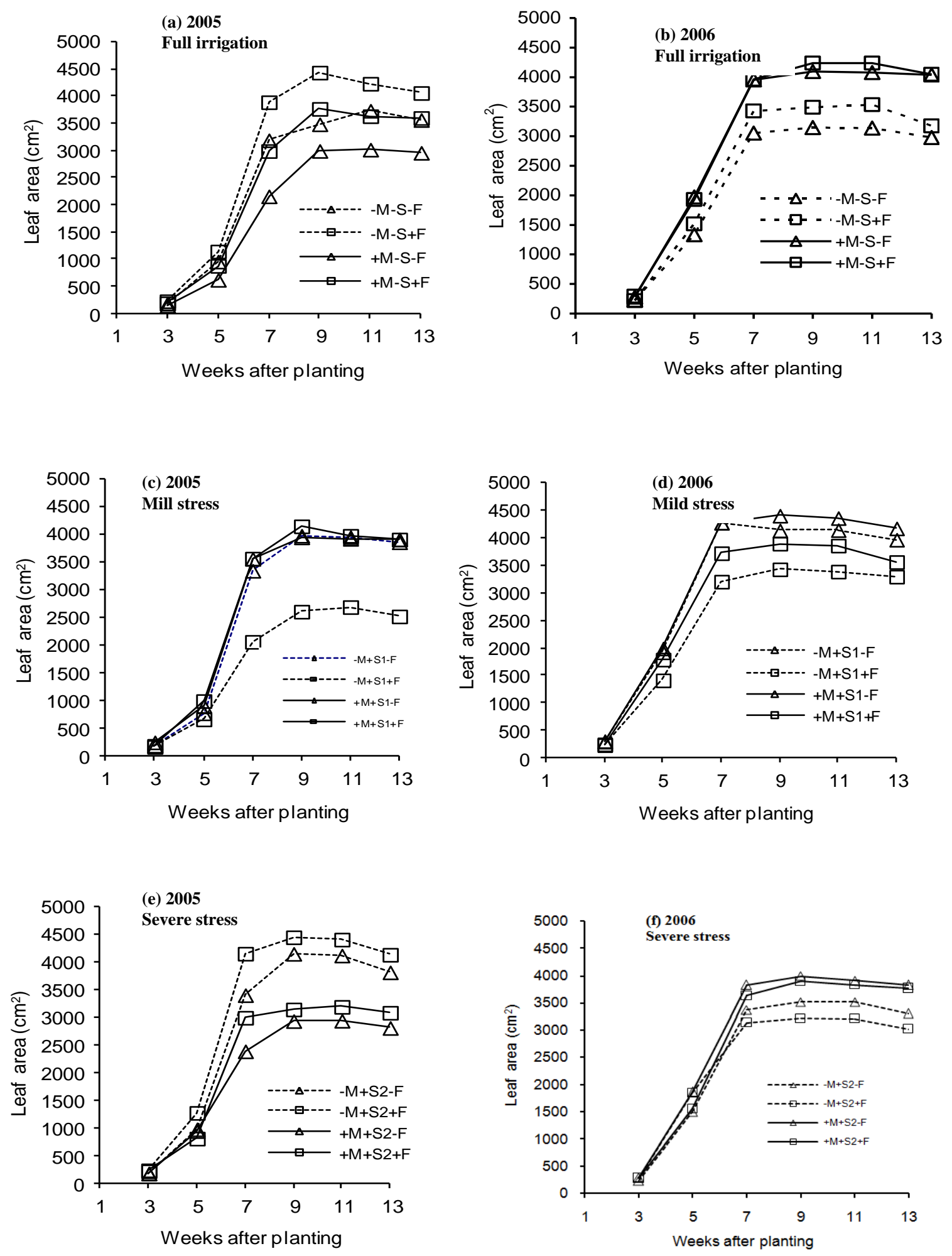

Fig.4 Leaf area of maize in response to varying treatment in 2005 and 2006 
Leaf area is dependent upon rate and duration of leaf expansion which is very sensitive to water and nitrogen availability. Water stress at early growth stage resulted in lower leaf area index. Water shortage reduced nutrient availability and subsequently photosynthesis process (Jazy et al., 2009). Optimum nitrogen availability enhanced assimilates accumulation and leaf expansion (Hammad et al., 2011) that finally boosted crop leaf area index (Awais et al., 2013).

The effect of the treatment applications (irrigation, mulching and fertilizer) on maize total shoot biomass are shown in Table 3 . Results show that the straw mulching significantly $(\mathrm{p}<0.05)$ increase dry weight of plant when compare with the no mulching treatment. This may be due to the capacity of mulching to effectively improve soil nutrient availability, increase plant growth (Fang et al., 2011) and influence soil physical and chemical properties (Jin et al., 2009). The effect of fertilizer is only significant in 2005, which is the first year of cropping.

The interactions of fertilizer mulch and fertilizer water significantly affect dry weight of plant and total aboveground biomass in 2005. During that period, the highest aboveground biomass (6564 $\mathrm{kg} \mathrm{ha}^{-1}$ ) was obtained under no mulch mild stress no fertilizer $(-\mathrm{M}+\mathrm{S} 1-\mathrm{F})$ and the lowest yield (3130 $\mathrm{kg} \mathrm{ha}^{-1}$ ) was recorded with no mulch mild stress plus fertilizer $(-\mathrm{M}+\mathrm{S} 1+\mathrm{F})$ treatment.

\section{Correlations between growth parameters}

Correlations between maize growth parameters in 2005 and 2006 are presented in Tables 4 and 5. It was found that most correlations between the growth characteristics were highly significant $(\mathrm{p}<0.01)$ and also that correlation coefficients were high. These high levels of correlations indicate that the physiological characteristics were highly dependent on each other. Results also revealed that correlation coefficients decreases with plant age.

The effects of combinations of deficit irrigation and straw mulch on growth yield and yield contributing parameters were studied in the green house. Rice straw reduces the amount of water needed to grow wheat irrespective of the severity of stress. Mild stress at seedling stage produces higher biomass. Deficit irrigation of wheat should coincide with earlier growth stages to ensure minimal yield reduction.

Further research should consider carrying this work on the field unlike the case here where all the parameters are controlled under the ambient greenhouse conditions.

\section{Competing interests}

The authors declare that they have no competing interests.

\section{Acknowledgements}

We are grateful for grants from the National Natural Science Foundation of China (50309003).

\section{References}

Awais, M., A. Wajid, W. Nasim, A. Ahmad and A. Bukhsh, 2013. Narrow plant spacing and nitrogen application enhances sunflower (Helianthus annus L.) productivity. Pak. J. Agri. Sci. 50(4): 689-697.

Bhattacharyya, R. S. Chandra, R. Singh, S. Kundu, A. Stivastva, and H. Gupta, 2007. Long term farmyard manure application effects on properties of a silty clay loam soil under irrigated 
wheat -soybean rotation. Soil Till. Res. 94: 386-396.

Bozkurt, S., A. Yazar and G.S. Mansuroglu, 2011. Effects different drip irrigation levels on yield and some agronomic characteristics of raised bed planted corn. African Journal of Agricultural Research 6: 5291-5300.

Chakraborty D, Nagarajan S, Aggarwal P, Gupta VK, Tomar RK, Garg RN, Sahoo RN, Sarkar A,

Cheema, M.A., M.A. Malik, A. Hussain, S.H. Shab, and S.M.A. Basra, 2001. Effects of time and rate of nitrogen and phosphorus application on the growth and the seed and oil yields of canola (Brassica napus L.). Journal of Agronomic Crop Science 186: 103-110.

Chopra UK, Sarma KSS, Kaira N. 2008. Synthetic and organic mulching and nitrogen effect on winter wheat (Triticum aestivum L.) in a semi-arid environment. Agricultural Water Management, 97: 738-748. DOI: https:// ideas.repec.org/a/eee/agiwat/v97y2010i 5p738-748.html

Dogan E., and H. Kimak, 2010. Water temperature and system pressure effect on drip lateral properties. Irrigation Science, 28: 407-419. DOI: 10.1007/s00271 -009-0202-z.

English, M., 2010. Deficit irrigation I. Analytical framework. Journal of Irrigation Drainage Engineering, 116: 399-410. DOI: http://dx.doi.org/ 10.1061/(ASCE)07339437(1990)116:3(399).

Erenstein, O., 2002. Crop residue mulching in tropical and semi-tropical countries: an evaluation of residue availability and other technological implications. Soil Till. Res 67, 115-133.

Fang, S.Z., B.D. Xie, D.Liu and J.J. Liu, 2011. Effects of mulching materials on nitrogen mineralization, nitrogen availability and poplar growth on degraded agricultural soil. New Forests 41: 147-162.

FAO. 2014. Crop prospects and food situation; Food and Agriculture Organisation, Global Information and early warning system, trade and market division (EST): Rome, Italy. http://www.fao.org/giews/reports/cropprospects/en/

FAO-AMIS., 2016. Agricultural Market Information System (AMIS). Retrieved December 19, 2016, from https://w ww.amis-outlook.org/home/en/

Hammad, H.M., A. Ahmad, A. Wjid and J. Akhter, 2011. Maize response to time and rate of nitrogen application. Pak. J. Bot. 43: 1935-1942.

Jazy, H.D., M.R. Poor, H.H. Abad and A. Souleimani, 2007. Growth indices of winter wheat as affected irrigation regimes under Iran conditions. Pak. J. Bio. Sci. 10 (24): 4495-4499.

Jin, K., S. Sleutel, D. Buchan, S. De Neve, D.X. Cai, and D. Gabriels, 2009. Changes of soil enzyme activities under different tillage practices in the Chinese Loess Plateau. Soil and Tillage Research. 104: 115-120.

Kaur, T. B.S. Brar, N. Dhillon, 2008. Soil organic matter dynamics as affected by long term use of organic and inorganic fertilizers under maize-wheat cropping system Nutr Cycl. Agroecosys 81: 5969.

Lamm, F. R., H. L. Manges, L. R. Stone, A. H. Khan and D. H. Roges, 2005. Water requirement of subsurface drip irrigated corn in northwest Kansas. Transactions of ASAE 38: 441-448.

Makus, D.J., S.C. Tiwari, H.A. Pearson, J.D. Haywood, and A.E. Tirks, 1994. Okra introduction with pine straw mulch. Agroforestry Sys. 27(2): 121-127.

Rahman MA, Chikushi J, Saifizzaman M, Lauren JG. 2005. Rice straw mulching and nitrogen response of no-till wheat 
following rice in Bangladesh. Field Crop Res. 91 (1): 71-81. DOI:10.1016/j.fcr.2004.06.010

Stone, L.R., A.J. Schlegel, RE Gwin, and A.H. Khan, 2006. Response of corn, grain sorghum, and sunflower to irrigation in the high plain of Kansas. Agricultural water Management 30: 251-259. DOI: http://doi.org/10.1016/ 0378-3774(95)01226-5.

Tahir, M.H.N., S. Bashir and A. Bibi. 2006. Genetic potential of canola (Brassica napus) varieties under water stress conditions. Caderno de pesquista Ser Bio Santa Cruz do Sul 18(2): 127-135.

Tollenaar, M. and E. A. Lee, 2011. Strategies for enhancing grain yield in maize. PL. Breed. Rev., 34: 37-81.

WMO, 2012. Agrometeorlogy of some selected crops. In Guide to Agricultural
Meteorological Practices (GAMP) (2010 ed., pp 1-128). Geneva: Chair Publications Board.

Yang JC, Zhang JH, Ye YX, Qang ZQ, Zhu QS, Liu LJ. 2004. Involvement of abscisic and ethylene in the responses of rice grains to water stress during filling. Plant Cell Environ, 27: 10551064.

Yazar, A., S.M. Sezen, and B. Gencel, 2012. Drip irrigation of corn in the Southeast Anatolia Project (GAP) area in Turkey. Irrigation and Drainage. 51: 293-300. DOI: 10.1002/ird.63.

Yildirim E. and S. Kodal, 2008. Effect of irrigation water on corn grain yield in Ankara conditions. Turkish Journal of Agriculture and Forestry 22: 65-70.

\section{How to cite this article:}

Abarchi Idrissa, Maman Nouri, Dahiratou Ibrahim Doka, Jimoh Saka, Zhang Zhan-Yu and Guo Xiang-Ping. 2018. Impact of Deficit Irrigation, Straw Mulch and Nitrogen Fertilizer on Vegetative Growth of Maize (Zea mays L.). Int.J.Curr.Microbiol.App.Sci. 7(09): 2348-2361. doi: https://doi.org/10.20546/ijcmas.2018.709.292 